\title{
Influence of Leader-Member Exchange, Perceived Organizational Support, Papua Ethnic Culture and Organizational Citizenship Behavior toward Employee Performance of Workers in Papua Provincial Secretary Office
}

\author{
${ }^{1}$ Arius Kambu, ${ }^{2}$ Eka Afnan Troena ${ }^{3}$ Surachman, ${ }^{4}$ Margono Setiawan \\ ${ }^{I}$ Economy Faculty of Cenderawasih University, Jayapura Papua Indonesia \\ ${ }^{2,3,4}$ Economy Faculty and Business of Brawijaya University, Malang Indoneia
}

\begin{abstract}
Objective for this study is to analyze and finding out the influence of leader-member exchange, perceived organizational support and culture (Papua ethnic culture) toward organizational citizenship behavior and its impact toward employee's performance. Access sample consist of 300 Papua-ethnic employees which has the opportunity to work for Papua Provincial Secretary Office. This study used statistical descriptive analysis to determine characteristic of respondent for each variables indicator. Meanwhile, to test relationship between variables, statistical descriptive analysis method and SEM with AMOS 6 approach was used. Result from this study has proven that good leader-member exchange is not yet able to form organizational citizenship behavior and improving employees' performance. For organizational support perception, culture (Papua ethnic culture) in partial is able to improving employees' performance through organizational citizenship behavior. In additional, results also showed that in order to enhance work discipline and better work ethos of employees, leader should consider local culture, communication and work commitment factors.
\end{abstract}

Key Words: Leader-Member Exchange, Papua Ethnic Culture, Organizational Citizenship Behavior, Perceived Organizational Support, Employees Performance

\section{Introduction}

Organizational working dynamic worldwide has shifted from working individual into work teams. Effectivity and team performance has been determined by ability of team member to work in team. However, not all people able to work in team since it need individual ability in open communication and honestly, working cooperatively with others, sharing information, recognizing difference and able to solve conflicts also able to suppressed personal interest for team interest. Robbins (2007) suggests that working in team difficulties has been experiencing by lots of employees in Western countries, since they have individualistic culture. In addition, before implementing working teams, work environment in Western countries has competitive nature which appreciates individual achievement. Therefore, team was expected to finely grow in countries with high collectivity value. According to Hofstede (1991), Indonesia is one country with high collectivity where group interest is above individual interest, thus working team system would grow well in Indonesia. Characteristic of Indonesian that highly valued togetherness and helping each other, along with high rank of Indonesia in collectivism dimension, has brought belief Indonesia would be able to show high OCB.

Endorsement of Regional Autonomy (Otonomi Daerah) started in January 1st, 2001 has brought vast and serious implication which consider to be political phenomenon that made centralistic government implementation move toward decentralistic UU/21/2001 concerning Special Autonomy for Papua Province in sub-clause ' $\mathrm{g}$ and $\mathrm{h}$ ' which mandate that government implementation and development realization in Papua still haven't fulfill fairness, people welfare, law enforcement, and respect toward Human Righst, particularly for native people of Papua. In order to reduce gap between Papua province and other province also to improve living standard of Papuan, and giving opportunities toward native Papuan, it needs special policies within Negara Kesatuan Republik Indonesia; implementation of special policy was meant to be based on basic values includes protection and appreciation toward ethics and moral, basic rights of native Papuan, Human Rights, legal supremacy, democracy, pluralism, and equal position, rights and duties as citizen.

Koentjaraningrat (1991) suggest that cultural value system developed among society has become an ideal guideline to take stance over certain objects, also toward economic development, or leadership development. As if cultural value determine one's attitude toward certain objects, in which cultural value system consists of living concepts among the minds of community majority. Thus, cultural value system within community is a specific characteristic and becoming sacred rules for behavior of each person within community and resulting those cultural values to sit on high position among the life of the people, and these cultural values has adheres also becoming difficult to represent social system since it is always change. 
Leader Member Exchange (LMX) also believed as the predictor of organizational citizenship behavior (OCB). Miner (1988) said that high quality interaction of superior-subordinate would bring impacts such as improving work satisfaction, productivity and employees performance. Riggio (1990) argued that if superiorsubordinate interaction is in high quality, a superior would have positive view toward its subordinate thus his subordinate would feel his superior has been given him support and motivation. This could improve selfconfident and elicited respect from subordinate toward their superior and they would be motivated to do 'more than' expected of their superior.

Good Perceived Organizational Support (POS) in their working life would create sense of 'moral duty' within self toward organization thus they would feel an obligation to pay for it. Shore and Wayne (1997) found out that perception toward organization support has become predictor of organizational citizenship behavior (OCB) and positively related with performance. Worker that feels they were supported by organization would be giving feedback and reducing imbalance in this relationship by involving within citizenship behavior. Therefore, interaction quality between superior-subordinate would be able to improve organization performance.

Organ (1988), Organization Citizenship Behavior (OCB) seen vastly as factors that contribute toward organization work results, in overall would consist of five dimension: (1) altruism, that is behavior in assists to demulcent work addressed for individual in an organization, (2) courtesy, helping peer to prevent problematic emergence related with work by giving consultation and information also by appreciating their needs, (3) sportsmanship, tolerance in less ideal situation occur in work place without complaining, (4) civic virtue, involving in organizational activities and concern toward organizational survival, (5) conscientiousness, that is doing things that would benefiting organization such as complying rules in organization.

Culture (Papua ethnic culture) is a differential variable with previous study and a variable that showed originality of this study.

The problem is what is the effect of LMX, POS, BP toward OCB and employees performance that occurs in SEKDA Papua province. Therefore, it is in need of study with objective to found out factors LMX, POS, BP and its influence over OCB and Employees Performance.

\section{Culture}

Mangkunegara (2005) quotes several argument from organizational culture expert such as according to Davis and Newstrom (2001), "organizational culture is the assumptions, beliefs, values and norm that is shared among its numbers,". Schein (1992) has argued that: An organizational's culture is a pattern of basic assumptions invented, discovered or developed by an given group as it learns to cope with its problems of external adaptation and internal integration that has worked well enough to be considered valid and to be taught to new members as the correct way to perceive, think and feel in relation to these problems.

While Davis (1984), argued that organization culture is a belief patterns and organization values that comprehended, believed and practiced by organization so this pattern has certain meaning and becoming the basis of behavioral rules within organization. Organization culture also consist of values and standard that directing behavior of organizational actors and determining organizational direction in overall.

Lako (2004), quoting Schein argument (1992), splitting organizational cultural level types, that is type (1) artifact is things seen, heard and felt if one is related with new group and unknown culture. Artifact includes art facts, work creation, and also behavior that could be seen and heard, level 2 (2) espoused value consist of values supported and becoming reason why one would sacrifice for it. Culture in most organization would be able to track values which supported back in culture and level 3 (3) underlying assumptions, that is assumptions which becoming basic of beliefs already exist by member of organization.

\section{Organization Culture}

Hofstede (1991) chose to define culture as mind pattern, feeling and action for social groups, which differentiate it with other social groups. Robbins (2007) define organization culture as together perception taken by organization member and becoming a system for shared meaning. Schein (2004) chose definition that could explain how culture grows, how culture could become like what it is, or how culture could be change if organization survival is at stake. Schein define organizational culture as:

A pattern of basic assumption that a given group has invented, discovered or developed in learning to cope with its problems of external adaptation and internal integration, and that have worked well enough to be considered valid and therefore, to perceive, think and feel in relation to choose problems.

On the other side, organization culture mostly defined as basic philosophy that gives direction for employee and consumers. Based on this definition, an important thing that should exist within organizational culture is a values system in which its meaning was felt by all members within organization. 


\section{Recognizing Papua Culture}

Papuan (people of Papua) that lived in west part of New Guinea island culturally put into one culture collective together with other inhabitant of Papua New Guinea, Salomons islands, Fiji, Panuatu and New Caledonian, which is called Melanesian culture. Papua ethnic culture is a values system that had become guidance for employees based on local regional culture as the guidelines to control behavior and member of organization in interacting with other organization (Van Den Broek, in Mansoben 2005). Indicator of Papua ethnic culture used in this study were those suggested by Mansoben (1995), Warami (2007) that is: (1) work ethos, (2) gotong royong (mutual assistance), (3) openness, (4) cultural value preservation, (5) phylogenetics, (5) consumptive pattern.

\section{Leader-Member Exchange}

Theory of LMX suggested that limited resource and lack of time available for each worker, superior has opportunities to develop a closely-knit social interaction or exchange only with several essential subordinate (in-group). Social exchange consists of mature and stable interpersonal within dyadic relationship (Graen, 1976, Graen and Cashman, 1975, Grawn and Scandura, 1987, Liden et al., 1997). Worker with no special relationship would be classified as out-group. For instance, when high LMX level existed, subordinate view himself as those who had good working relation with their supervisor and know how to satisfy their superior by their performance (Graen, Novak and Sommerkamp, 1982). Theory base of LMX and empirical support is based on role theory (Katz and Kahn, 1978) and social exchange relationship (Blau, 1964). Basic of LMX has initial theory fundamental and empiric evidence in role theory (Liden, Sparrowe and Wayne, 1997). Each individual is expected to play special role in organization (Katz and Kahn, 1978). LMX indicator used in this study is those suggested by Augusta, Hartman and Gale, 1999 that are: coordination, expression, participation, and freedom to ask.

\section{Perceived Organizational Support}

Social interaction process could occur between individual and individual, individual and groups, group and group. In organization, social interaction could occur in individual with its organization context. Concerning this, organizational support concept tried to explained individual interaction with organization particularly examining how organization treated their individuals (employees).

Perceived organizational support is global belief developed by employees concerning how far organization committed to them viewed from organization appreciation toward their contribution and organization attention toward their work-life (Wayne et al., 1997). In this study, indicator of perceived organizational support (POS) consists of four indicators taken from Eisenberg et al, (1986): a) rewards; b) assessment; c) development and d) involvement.

\section{Organizational Citizenship Behavior}

Organ (1988) also defined OCB as organizational beneficial behavior and attitude that could not be grown with formal role duty basis or with contract or re-compensation. OCB being viewed as factor that give contribution in overall organization work. Organ (1988) mention five aspect of OCB, that is: (a) conscientiousness, means employees has in-role behavior that fulfilling level above minimum requirement standard; (b) altruism, that is willingness to give help toward others; (c) civic virtue, active participation of employees in thinking about organization life, such as: always looking for latest information that supporting organization advance; (d) sportsmanship, giving more emphasis in organizational positive aspects than its negatives, indicating attitude of not-protesting, not complaining and not exaggerate small matters, (e) courtesy, by good deed and respecting others, such as attitude in helping someone to prevent problem to occur, or making steps to reduce the emergence of a problem.

\section{Performance}

Benardin and Russel (1993) argued that performance defined as follows. Performance is defined as the record of outcomes produced on a specified job function or activity during a specified time period. (Work achievement is notes concerning results obtained and particular job function or certain activities in certain time period. Performance indicator used in this study was based on indicator suggested by Armstrong (2004), Mondy, Sharplin, Flippo (1995), LAN (1992), that were: 1) job result quantity, 2) job result quality, 3) punctuality.

\section{Method}

Data analysis to found out effect of LMX, POS, BP that influencing OCB and employees' performance used as independent variables, and LMX, POS, BP toward OCB formation and employees' performance used as dependent variables. SEM analysis and path coefficient also significance level used in this study to found out 
the effect of LMX, POS, BP toward OCB formation and employees' performance. SEM according to Hair, (2006) was as follows: (1) theory-based model development; (2) path diagram development; (3) conversion of path diagram into structural equation and measurement model; (4) choosing input matrix and model estimation; (5) possibility of identification problems; (6) evaluation in criteria goodness of fit; (7) interpretation and model modification.

Model Appropriation Analysis

\section{Results}

Analysis results of final structural model resulting good model. All appropriateness/compatibility in chi-square, RMSEA, GFI, AGFI, CFI of the model is also good.

Table 1. Goodness of fit Calculation in final model index

\begin{tabular}{|l|l|l|l|}
\hline Criteria & Cut-off value & Model result & Information \\
\hline Chi-quadrate & Expected small & 88,4 & $\begin{array}{l}\text { Small, X2 (5\%, 98) } \\
122,11\end{array}$ \\
\hline P_value & $\geq 0,05$ & 0,746 & Good \\
\hline Cmin/df & $\leq 0,20$ & 0,902 & Good \\
\hline GFI & $\geq 0,90$ & 0,906 & Good \\
\hline AGFI & $\geq 0,90$ & 0,908 & Good \\
\hline CFI & $\geq 0,90$ & 1,000 & Good \\
\hline TLI & $\geq 0,90$ & 1,005 & Good \\
\hline RMSEA & $\leq 0,08$ & Good \\
\hline
\end{tabular}

\section{Descriptive Statistics}

Based on structural model and hypothesis testing, this discussion describes study variables by viewing mean value or loading factor value also related discussion with direct or indirect effect based on theory or empirical facts support and previous study. Last part of discussion would present study's contribution and limitation. From this various explanation, it suggests that mean and loading factor of each variable could be seen from Table 2 as follows:

Table 2. Mean and Loading Factor

\begin{tabular}{|l|l|l|l|l|}
\hline Variables & Indicator & Loading Factor & $\begin{array}{l}\text { Score Mean } \\
\text { Indicator }\end{array}$ & $\begin{array}{l}\text { Score Mean } \\
\text { Variable }\end{array}$ \\
\hline \multirow{2}{*}{$\begin{array}{l}\text { Leader-Member } \\
\text { Exchange (LMX) }\end{array}$} & Coordination (LMX1) & 0.951 & 3.11 & 3,32 \\
\cline { 2 - 4 } & Expression (LMX2) & 0.791 & 3.07 & \\
\cline { 2 - 4 } & Participation (LMX3) & 0.878 & 3.17 & \\
\hline \multirow{2}{*}{$\begin{array}{l}\text { Perceived } \\
\text { Organizational }\end{array}$} & Rewards (POS1) & 0.820 & 3.21 & \\
\cline { 2 - 4 } & Assessment (POS2) & 0.766 & 3.48 & \\
\cline { 2 - 4 } & Development (POS3) & 1.014 & 3.31 & \\
\cline { 2 - 4 } & Involvement (POS4) & 0.917 & 3.34 & \\
\hline
\end{tabular}

Table 2.

\begin{tabular}{|c|c|c|c|c|}
\hline \multirow{7}{*}{$\begin{array}{l}\text { Papua Ethnic Culture } \\
\text { (BP) }\end{array}$} & Work Fthoc (RD1) & & & \multirow{7}{*}{3,23} \\
\hline & WOIK ECIOS (DP1) & 0.025 & 5.22 & \\
\hline & Helping each other (BP2) & 0.610 & 3.26 & \\
\hline & Openness (BP3) & 0.650 & 3.45 & \\
\hline & $\begin{array}{ll}\text { Cultural } & \text { value } \\
\text { preservation (BP4) } & \\
\end{array}$ & 0.886 & 3.18 & \\
\hline & Phylogenetic (BP5) & 0.668 & 3.23 & \\
\hline & $\begin{array}{l}\text { Consumpti.ve pattern } \\
\text { (BP6) }\end{array}$ & 0.942 & 3.12 & \\
\hline \multirow{5}{*}{$\begin{array}{l}\text { Organizational } \\
\text { Citizenship Behavior } \\
\text { (OCB) }\end{array}$} & Altruism (OCB1) & 0.958 & 3.02 & \multirow[t]{5}{*}{3,08} \\
\hline & $\begin{array}{l}\text { Conscientiousness } \\
\text { (OCB2) }\end{array}$ & 0.978 & 3.07 & \\
\hline & Sportmanship (OCB3) & 0.822 & 3.15 & \\
\hline & $\begin{array}{lr}\text { Involvement } \\
\text { organizational } \\
\text { (OCB4) }\end{array}$ & 0.512 & 3.07 & \\
\hline & $\begin{array}{l}\text { Keeping Information } \\
\text { (OCB5) }\end{array}$ & 0.900 & 3.09 & \\
\hline Employees' & Quantity (KP1) & 1.070 & 3.08 & 2,97 \\
\hline
\end{tabular}


Influence of Leader-Member Exchange, Perceived Organizational Support, Papua Ethnic

\begin{tabular}{|l|l|l|l|l|}
\hline \multirow{2}{*}{ Performance } & Quality (KP2) & 0.534 & 2.81 & \\
\cline { 2 - 4 } & Punctuality (KP3) & 0.523 & 3.02 & \\
\hline
\end{tabular}

Based on analysis result of final structural model, in this discussion section, study variable would be described by viewing effect of independent variables toward dependent variable which could done by using t-test, therefore relationship from analysis result could be seen from Table 2.

Table 2. Path coefficient of several factors LMX, POS and BP that affecting OCB and Employees Performance

\begin{tabular}{|l|l|l|l|l|}
\hline $\begin{array}{l}\text { Dependent } \\
\text { Variable }\end{array}$ & $\begin{array}{l}\text { Independent } \\
\text { Variable }\end{array}$ & Path Coefficient & P-value & Decisions \\
\hline Direct Effect & LMX & 0,043 & 0,328 & Rejected \\
\hline KP & POS & 0,043 & 0,281 & Rejected \\
\hline KP & $-0,041$ & 0,454 & Rejected \\
\hline KP & BP & & Rejected \\
\hline Indirect Effect & LMX & $-0,047$ & 0,030 & Accepted \\
\hline OCB & 0,152 & 0,012 & Accepted \\
\hline OCB & POS & 0,368 & 0,000 & Accepted \\
\hline OCB & BP & 0,661 & 0,000 & \\
\hline KP & OCB & &
\end{tabular}

In Table 2 it showed that direct and indirect effect between good and significant or insignificant study variable might be explained as follows: (1) direct effect of LMX toward employees performance obtain path coefficient 0.043 , p-value 0.328. Since p-value is $>0.05$, it showed that employees perception concerning LMX still had not improving employees performance; (2) direct effect of POS toward employees performance obtain path coefficient 0.043 , p-value 0.281 . Since p-value $>0.05$, it indicates that there is no direct effect between POS and employees performance; (3) cultural direct effect (Papua ethnic culture) toward employees performance obtain path coefficient -0.041 , p-value 0.454. Since p-value $>0.05$, it indicates no direct effect between culture (Papua ethnic culture) toward employees performance; (4) indirect effect between LMX toward OCB obtain path coefficient -0.047 , with $\mathrm{p}$-value 0.530 . Since $\mathrm{p}$-value $>0.05$, it indicates indirect effect between LMX toward OCB; (5) indirect effect of POS toward OCB obtain path coefficient 0.152 , p-value is 0.012 . Since p-value $<0.05$, it indicates indirect effect between POS and OCB; (6) indirect effect between culture (Papua ethnic culture) toward OCB obtain path coefficient 0.368 , with p-value 0.000 . Since p-value $<0.05$, it indicates indirect effect between culture (Papua ethnic culture) toward OCB; (7) indirect effect between OCB and employees performance obtain path coefficient 0.661 , with $\mathrm{p}$-value 0.000 . Since p-value $<0.05$, it indicates indirect effect between OCB and employees performance.

\section{Discussion}

\section{Indirect Effect of Leader-Member Exchange with Organizational Citizenship Behavior}

Result of this study showed that employees' perception concerning LMX still haven't able to improve OCB. LMX has lack of role in forming employees' OCB. Finding in this study didn't support finding from Ferry (2007), Asgari (2008), Liang and Crant (2010), Yun (2007), Kashif Khan and Rafi (2011), Law and Wang (2001), whereas LMX has significant effect toward OCB. This study also didn't strengthened Wayne (1997) theory, that suggested employees with high interaction quality toward his superior could do other task in addition with their ordinary task, while employee with low interaction quality toward his superior tend to show routine task. From a work group, OCB could be defined as an attitude conducted more than just a basic attitude in accord with contract agreed by an employee.

\section{Indirect Effect of Perceived Organizational Support with Organizational Citizenship Behavior}

Analysis result showed that employees' perception concerning POS is able to improve OCB. Path coefficient with positive mark indicates that stronger POS would be able to improve OCB. This is in line with previous study conducted by Ferry (2007) that suggested perceived organizational support (POS) is related with OCB. Asgari (2008) suggested positive relationship between POS and OCB. Liang and Crant (2010) argued interaction between organizational supports (POS) toward OCB. Douglas (2002), Begum (2005), Miao (2011), Moorman, Blakely and Niefhof (1993) suggests that perceived organizational support (POS) has affecting OCB. This study strengthened Eisenberger (1986) theory, that mention employees or individuals within organization would develop a global belief to determina organizational personification readiness in giving reward toward improving work efforts and meeting employees' needs to be appreciated and rewarded. Employees with good perceived organizational support would try as best as he could to repay goodness he received from organization. 


\section{Indirect Effect of Papua Ethnic Culture with OCB}

Analysis result reveals that culture (Papua ethnic culture) is able to improve OCB. This indicate that values system which become guidance by employees based on local regional culture has controlled organization member in interacting with organization to bring work attitude that supporting effectivity and efficiency of organization function. This results support previous study, Markoczy (2004) argued that culture has affecting OCB. This study strengthened Hofstede (1991) theory, which classified four basic problem areas considered as culture dimension, which are: (1) social inequality, including relationship with authority holder; (2) relationship between individual and groups; (3) concept of masculinity and femininity, a social implication in gender difference; and (4) attitude toward incertainty, related with control toward aggressivity and emotional expression.

\section{Indirect Effect of Organizational Citizenship Behavior with Employees Performance}

Result of analysis showed that OCB is able in improving employees' performance. This indicate that organization has formed organizational citizenship behavior in attitude of replacing others in working, exceeding minimum requirement, tolerance willingness, involved in organizational function and able to keep information. This results is in line with previous study conducted by Podsakoff et al. (2000), that OCB has role in improving performance. This study strengthened Organ (1988) theory; Podsakoff and MacKenzie, 2007 in Bolino, Turnley and Bloodgood (2002), specifically OCB could affect organizational performance in matters such as: (1) encourage productivity improvement of manager and employees; (2) encourage resources utilization owned by organization for specific aims; (3) reducing needs to use rare organizational resources in maintenance function; (4) facilitating coordination activity between team member and work groups; (5) improving organizational ability in maintain and retain high quality employee by making work environment to become a place more fun to for work; (6) increasing stability of organizational performance by reducing variety of performance from each organizational units; (7) increasing organizational ability to adapt with environmental changes.

\section{Direct Effect of Leader-Member Exchange with Employees Performance}

Employees' perception concerning LMX is not yet able to improve employees' performance. It mean that higher LMX still not yet able to improve employees' performance. From statistic analysis results, it reveals that in general, respondents' perception toward LMX is not good enough, where superior still lacking in coordination function, such as giving explanation concerning changes in job task, work procedures, work plan and problems related with job. This finding didn't support finding of Law and Wang (2001), Liang and Crant (2010) which has significant relationship toward employees performance. This study strengthened Landy (1989) theory which suggest that low quality of superior-subordinate interaction, would be featuring: (1) formal interaction of superior-subordinate, therefore a superior would use authority power in affecting his subordinate; (2) there was low role-negotiation level in which superior-subordinate interaction would be limited by roles being played; (3) superior seldom talking with his subordinate concerning task effectivity; (4) superior seldom helping his subordinate by giving him different task.

\section{Direct Effect of Perceived Organizational Support with Employees Performance}

Perceived organizational support is still not yet able to improve employees' performance. This showed that stronger perceived organizational support has no effect toward improvement in employees' performance. Perceived organizational support all these years is more likely to be operating on its own without any relationship with performance.

This result didn't support Douglas (2002) finding, which suggest existing relationship between POS and performance. This result strengthened Anthony (1998) theory which argued that management problem solving in motivating people to conduct in line with organizational objective generally lies in relationship between organizational incentives with personal expectations.

\section{Direct Effect of Papua Ethnic Culture with Employees Performance}

This result gives description that culture (Papua ethnic culture) directly not yet able to improve employees' performance by obtaining negative coefficient value. This means that it is important for superior to understand value system which becomes guidance for local regional culture in controlling employees' behavior within organization. This result didn't support previous finding by O'Regan, Ghobadian (2004), and Ojo (2009) which argued that organizational culture has significant relationship with employees' performance. This study strengthened Atmosoeprapto (2001) theory, which suggest several organizational culture elements would be determined by: (1) environment, environment where organization operates would determine what should be done by organization to achieve success; (2) values as basic concepts and belief in an organization; (3) role model, people who become role-model for other employees because of his/her success; (4) ceremonial events 
(rites \& rituals), routine events held by organization in order to give reward for their employees; (5) network, information communication network within an organization which could become facility in spreading organizational culture values.

\section{Conclusions}

Employees' perception concerning LMX in direct manner still hasn't been able to increase employees' performance, this is caused by weak communication relationship between superior-subordinate that should give input for superior, in decision making process sometimes superior didn't give enough information concerning problems faced by their employees in an open manner.

Employees' perception concerning organizational support in direct manner still hasn't been able to improve employees' performance. This might be caused by rewards perceived by employees globally would include: return, attention and work achievement received by employees either financial or non-financial still not equivalent with work load conduct by employees.

Culture (Papua ethnic culture) in direct manner still hasn't been able to improve employees' performance this might be caused be loose work culture which includes: work discipline, work ethos, and good work-time management, which might cause most Papuan employees has low performance.

\section{Reference}

[1] Amstrong, Machael. 2004. Performance Management. Tugu Publisher. Yogyakarta Anthony, R. N., Dearden, J., and Bedford. 1998. Management Control System. Chicago: Irwin Asgari, 2008. The-relationship-between-transformational-leadership-behaviorsorganizational-justice-leader-member.http://textedu.com/f2/download/the-relationship-between-transformational-leadershipbehaviors-organizational-justice-leader-member.pdf. Tanggal akses 11 maret 2011

[2] Atmosoeprapto, Kisdarto, 2001, Actualization Productivity Corporate Culture. PT. Elex Media Komputindo, Jakarta.

[3] Augusta, Hartman dan Gale (1999). Leader-member exchange quality and effectiveness ratings. Group and Organization Management, 20 (2), 189-216. Tanggal Maret 2011

[4] Begum, 2005. The Relationships Between Social Power And Organizational Citizenship Behavior: The Mediational Role Of Procedural Justice, Organizational Commitment, And Job Satisfaction In Context Of A Private Commercial Bank In Bangladesh. Independent University, Bangladesh April 2005

[5] Bernandin,H.John, and Joyce E.A Russell. 1993. Human Resource Management: An Experiental Appraisal, Singapore: McGrawHill, Inc.

[6] Blau, P. M. 1964. Exchange and Power in Social Life. New York: Wiley.

[7] Bolino, M.C., Turnley, W.H., dan Bloodgood, J.M. 2002. "Citizenship Behavior and the Creation of Social Capital in Organization". Academy of Management Journal, Vol. 7, No. 4, 2002 pp. $502-522$

[8] Davis K, Newstrom JW, 2001. Behavior in Organizations. Volume 1, Translation. Jakarta, the publisher Erlangga

[9] Douglas. 2002. Organizational Perceptions And Their Relationships to Job Attitudes, Effort, Performance, And Organizational Citizenship Behaviors. A Dissertation. Submitted to the Graduate Faculty of the Louisiana State University and Agricultural and Mechanical College in partial fulfillment of the requirements for the degree of Doctor of Philosophy The Department of Psychology. December, 2002

[10] Eisenberger, R., Huntington, R., Hutchison, S., and Sowa, D. 1986. Perceived Organizational Support. Journal of Applied Psychology, Vol. 71(3): pp.500-507.

[11] Ferry, 2007. Employee Organizational Citizenship Behavior Seen From Perception Interaction Quality-Shirts And Tops Perception of Organizational Support http://repository.usu.ac.id/handle/123456789/15723 Vol. 2 No.. June 1, 2006, access date March 11, 2011

[12] Graen, G. B., and Scandura, T. A. 1987. Toward a psychology of dyadic organizing. Research in Organizational Behavior, 9, pp.175-208.

[13] Graen, G. B., Liden, R., and Hoel, W. 1982. Role of leadership in the employee withdrawal process. Journal of Applied Psychology, 67, pp.868-872.

[14] Graen, G. B., Novak, M, and Sommerkamp, P. 1982. The effects of leader-member exchange and job design on productivity and satisfaction: Testing a duel attachment model. Organizational Behavior and Human Performance, 30, pp.109-131.

[15] Graen, G.B. 1976. Role-making process within complex organizations. In M.D. Dunnette (Ed.), The handbook of industrial and organizational psychology (pp.1201-1245). Chicago: Rand McNally.

[16] Graen, G.B., and Cashman, J. 1975. A role-making model of leadership in formal organizations: a developmental approach. In J.G. Hunt \& L.L. Larson (Eds.), Leadership frontiers (pp.143-166). Kent, OH: Kent State University Press. 16.

[17] Graen, G.B., and Scandura, T.A. 1987. Toward a psychology of dyadic organizing. In L.L. Cummings \& B.M. Staw (Eds.), Research in organizational behavior

[18] Graen, G.B., and Uhl-Bien, M. 1998. Relationship-based approach to leadership: Development of leader-member exchange (LMX) theory over 25 years: Applying a multi-level multi-domain perspective. Leadership Quarterly, 6, pp.219-247.

[19] Hair. 2006. Multivariate Data Analysis, Fifth edition. New Jersey. Prentice Hall.

[20] Hofstede G. 1991. Culture and Organization: Software of The Mind. McGraw-Hill. New York

[21] Kasih Khan and Rafi, 2011. An Exploration of the Determinants of OCB in the Telecommunication Sector of Pakistan. Asian Journal of Business Management: 91-97, 2011. ISSN: pp.2041-8752.February 03, 2011

[22] Katz, D., and Kahn, R. 1978. The social psychology of organizations. New York: Wiley Koenjaraningrat, 1991. Culture, mentality, and Development. Scholastic, Jakarta.

[23] Lako, 2004. Leadership and Organizational Performance Theory Issues and Solutions. Amara Books, Yogyakarta.

[24] Landy, F. J. 1989. Psychology of Work Behavior. California: Brooks/Cole Publishing Company.

[25] Institute of Public Administration (LAN). 1992. Performance Improvement Planning, A Planning Approach for Performance Improvement (Performance of Work), Jakarta. 
[26] Liang and Crant, 2010. The Role of Proactive Personality in Job Satisfaction and Organizational Citizenship Behavior: A Relational Perspective. Journal of Applied Psychology 2010, Vol. 95, No. 2, p.395-404. http://psycnet.apa.org/index.cfm?fa=buy.optionToBuy\&id=2010-04488-015. Tanggal 11 Maret 2011

[27] Liden, R. C., Wayne, S. J., and Stilwell, D. 1997. A Longitudinal Study on the Early Development of Leader-Member Exchanges. Journal of Applied Psychology, Vol. 78: pp.662-674.

[28] Mangkunegara, 2005. Behavioral and Cultural Organization. PT. Refika Aditama, London First published

[29] Mansoben JR, 1995, Ethnography Papua Cenderawasih University, Jayapura Papua

[30] Marko'czy, 2004. The virtues of omission in Organizational Citizenship Behavior. Anderson Graduate School of Management University of California, Riverside. August 24, 2004

[31] Mendagri. 1999. Undang-Undang Otonomi Daerah 1999, Jakarta : Sinar Grafika,.

[32] Miao, 2011. Perceived Organizational Support, Job Satisfaction, Task Performance and Organizational Citizenship Behavior in China. Institute of Behavioral and Applied Management. All Rights Reserved.

[33] Miner, J. B. 1988. Organizational Behavior: Performance and Productivity. New York: Random House, Inc

[34] Mondy, R. Wayne, Arthur Sharplin and Edwin B. Flippo. 1995. Management: Concepts and Practices. Fourth Edition. Boston. Allyn and Bacon

[35] Moorman, R.H., Blakely, G.L. and Niehoff, B.P 1993. New Frontiers for OCB Research: An Examination of Four New Research Directions. Academy of Management St. Louis, MO . April 3-5, 2003

[36] O'Regan dan Ghobadian 2004. Short and longterm performance in manufacturing SMEs. Different targets, different drivers". Journal of Management, Vol. 5 : pp.159-180.

[37] Ojo, 2009. Impact Assessment Of Corporate Culture On Employee Job Performance. Business Intelligence Journal - August, 2009 Vol. 2 No. 2

[38] Organ, D. W,1988. Organizational Citizenship Behavior : The Good Soldier Syndrome. Lexington, MA: Lexington Books

[39] The Provincial Government, the Special Autonomy Law of Papua, 2001. http://www.theceli.com/dokumen/produk/2001/212001.htm. Access date May 24, 2011.

[40] Podsakoff, P.M.,MacKenzie, S.B., Paine, J.B., dan Bachrach, D.G. 2000. "Organizational Citizenship Behavior: a Critical Review of Theoretical Empirical Literature and Suggestions for Future Research". Journal of Management, 26 (3): 5 pp.13-563

[41] Riggio, R. E. 1990. Introduction to Industrial/Organizational Psychology. Illinois: Scott, Foresman, and Company.

[42] Robbins, 2007, Organizational Behavior, Indonesian Edition, Volume I and II, Prinhalindo, Jakarta.

[43] Schein,1992,Organization Culture and Leadership, Second Edition, Jossey-Bass Publihser, San Francisco California

[44] Shore, L. M. and Wayne, S. J. 1993. Commitment and Employee Behavior: Comparison of Affective Commitment and Continuance Commitment with Perceived Organizational Support. Journal of Applied Psychology, Vol. 78(5): pp.774-780.

[45] Sparrowe, R. T., Soetjipto, B. W., and Kraimer, M. L. (inpress). Do leaders' influence tactics relate to members' helping behavior? It depends on the quality of the relationship. Academy of Management Journal.

[46] Sparrowe, R.T., and Liden, R.C. 1997. Process and structure in leader-member exchange. Academy of Management Review, 22(2), pp.522-552

[47] Uhl-Bien, M., Graen, G. B., and Scandura, T. A. 2000. Implications of leader-member exchange (LMX) for strategic human resource management systems: Relationships as social capital for competitive advantage. Research in Personnel and Human Resource Management, 18, pp.137-185.

[48] Law. No. 32/2004 Concerning Local Government, Depatemen Affairs of the Republic of Indonesia, 2006

[49] Wang and Law, 2001. The Linkage Role of LMX: A Mediating Effect of LMX on the Relationship between Transformational Leadership and Followers' Performance and OCB. Department of Management of Organizations The Hong Kong University of Science and Technology Clear Water Bay, Kowloon Hong Kong

[50] Warami, 2007. Parallelism In Dou Sandik Guyub Speech Numfor Biak - Papua. Journal Vol. 14, no. 27, September 2007

[51] Wayne, S. J., Shore, L. M., and Liden, R. C. 1997. Perceived Organizational Support and Leader-Member Exchange: A Social Exchange Perspective. Academy of Management Journal, Vol. 40: pp.80-111.

[52] Wayne, S. J., Shore, L. M., Bommer, W. H. and Tetrick, L. E. 2002. The Role of Fair Treatment and Rewards in Perceptions of Organizational Support and Leader-Member Exchange. Journal of Applied Psychology, Vol. 87: pp.590-598.

[53] Yun, 2007. Leadership and Teamwork: The Effects of Leadership and Job Satisfaction on Team Citizenship. International Journal of Leadership Studies, Vol. 2 Iss. 3, 2007, pp. 171-193 @2007 School of Global Leadership \& Entrepreneurship, Regent University ISSN pp.1554-3145. 